\title{
NEW GENERALIZATION OF GAUSS-PÓLYA'S INEQUALITY
}

\author{
S. AbRAmovich, J. PEČARIĆ AND S. VAROŠANEC
}

Abstract. We consider inequality of Hölder's type

$$
\frac{\int_{a}^{b} w_{3}(x) g(x) d x}{\int_{a}^{b} w_{3}(x) d x} \leqslant \prod_{i=1}^{2}\left(\frac{\int_{a}^{b} w_{i}(x) g(x) d x}{\int_{a}^{b} w_{i}(x) d x}\right)^{1 / p_{i}}, \quad \frac{1}{p_{1}}+\frac{1}{p_{2}}=1,
$$

and give a number of results about functions $w_{1}, w_{2}, w_{3}$ which satisfy the above-mentioned inequality. Also, in a similar way, we consider an inequality of Minkowski's type.

Mathematics subject classification (1991): 26D15.

Key words and phrases: Hölder's inequality, Minkowski's inequality, right balanced function, left balanced function, convex function.

\section{REFERENCES}

[1] S. Abramovich, Monotonicity of eigenvalues under symmetrization, Siam J. Appl. Math., 29 (1975), 350-361.

[2] A. M. FInK AND M. JodeIT JR., Jensen Inequalities for Functions with Higher Monotonicities, Aequationes Mathematicae, 40, (1990), 26-43.

[3] C. F. GAUSS, Theoria combinationis observationum 1821., German transl. in Abhandlungen zur Methode der kleinsten Quadrate, Neudruck, Würzburg 1964, pp. 9 and 12.

[4] G. H. Hardy, J. E. LitTlewoOd AND G. Pólya, Inequalities, Cambridge Univ. Press, 1967.

[5] D. S. Mitrinović, J. E. PEČArić AND A. M. FinK, Classical and New Inequalities in Analysis, Dordrecht, Kluwer Acad. Publishers, 1993.

[6] B. Mond, J. PeČArić, J. Šunde And S. VArošAnec, Inequalities of Pólya Type for Positive Linear Operators, Houston J. Math., 22, 4 (1996), 851-858.

[7] J. PeČAriĆ, J. Šunde AND S. VARoŠAnEC, On Gauss-Pólya's Inequality, Anzeiger. Öster. Akad. Wiss. Math. - Naturwiss. Klasse (to appear)

[8] J. PEČARIĆ AND S. VAROŠANEC, A Generalization of Pólya's Inequalities, Inequalities and Applications, World Scientific Publishing Company, Singapore, (1994), 501-504.

[9] - Remarks on Gauss-Winckler's and Stolarsky's Inequality, Utilitas Math. 48 (1995), $233-241$.

[10] G. Pólya AND G. SzEGÖ, Aufgaben und Lehrsätze aus der Analysis, I,II, Berlin, 1925.

[11] S. VAROŠANEC, Inequalities of Minkowski's Type, Real Analysis Exchange, 20, No 1, (1994-95), $250-255$

[12] S. VAROŠAnEC AND J. PEČArIĆ, Gauss' and Related Inequalities, Z. Anal. Anwendungen, 14, No 1, (1995), 175-183.

[13] Some Integral Inequalities, with Application to Bounds for Moments of a Distribution, J. Austral. Math. Soc. Ser. B, 38, 3, (1997) 325-335.

[14] S. VArošAnec, J. PeČArić And J. Šunde, Some discrete inequalities, Z. Anal. Anwendungen, 15 (1996) 4, 1025-1032. 